\title{
Magnesium sulphate complexes with hexamethylenetetramine and 1,10-phenanthroline
}

\author{
Thermal, structural and spectroscopic properties
}

\author{
Tomasz Sieranski $\cdot$ Rafal Kruszynski
}

Received: 17 February 2011/ Accepted: 24 May 2011/Published online: 10 June 2011

(C) The Author(s) 2011. This article is published with open access at Springerlink.com

\begin{abstract}
The magnesium sulphate complex compounds of general formulae $\left[\mathrm{Mg}\left(\mathrm{H}_{2} \mathrm{O}\right)_{6}\right]^{2+} \cdot 2\left(\mathrm{C}_{6} \mathrm{H}_{12} \mathrm{~N}_{4}\right) \cdot \mathrm{SO}_{4}{ }^{2-}$. $5\left(\mathrm{H}_{2} \mathrm{O}\right)$ (1) and $\mathrm{Mg}\left(\mathrm{C}_{12} \mathrm{H}_{8} \mathrm{~N}_{2}\right)\left(\mathrm{H}_{2} \mathrm{O}\right)_{3} \mathrm{SO}_{4}$ (2) have been synthesized, characterised by elemental and thermal analysis, IR, UV-VIS and fluorescence spectroscopy, and $\mathrm{X}$-ray crystallography. The obtained compounds are air stable at room temperature and well soluble in water. In the structures of the investigated complex compounds the $\mathrm{O}-\mathrm{H} \cdots \mathrm{O}, \mathrm{O}-\mathrm{H} \cdots \mathrm{N}$, and $\mathrm{C}-\mathrm{H} \cdots \mathrm{O}$ hydrogen bonds exist, and they create $\mathrm{N}_{2} \mathrm{C}_{2}^{2}(8), \mathrm{R}_{2}^{2}(8)$ (compound $\mathbf{1}$ ) and $\mathrm{N}_{1} \mathrm{C}_{1}^{1}(6)$, $\mathrm{N}_{1} \mathrm{R}_{2}^{2}(12)$ (compound 2) patterns. Their thermal decomposition processes in the investigated atmospheres (air and helium) are different. After the slightly similar dehydratation, the observed transitions and the obtained final products are different (in helium atmosphere the sulphate ion of studied compounds undergoes decomposing what does not take place in air atmosphere). The UV-VIS spectrum of $\mathbf{2}$ shows maxima that are typical for $\pi \rightarrow \pi^{*}$ and $n \rightarrow \pi^{*}$ transitions, and fluorescence spectrum of the same compound displays its great fluoresce properties. The $\mathbf{1}$ does not exhibit absorption in the investigated region of electromagnetic spectrum due to the absence of respect chromophore groups. The IR spectrum of $\mathbf{2}$ shows typical vibrations for chelating amine molecule. An interesting fact is that in $\mathbf{1}$ the SO stretching vibrations (existing at 1119 and $1182 \mathrm{~cm}^{-1}$ ) are doubled in comparison to the magnesium sulphate whilst in $\mathbf{2}$ these vibrations are absent.
\end{abstract}

T. Sieranski · R. Kruszynski $(\bowtie)$

Institute of General and Ecological Chemistry, Technical University of Lodz, Zeromskiego 116, 90-924 Lodz, Poland

e-mail: rafal.kruszynski@p.lodz.pl
Keywords Magnesium - Sulphate ·

Hexamethylenetetramine $\cdot$ 1,10-Phenanthroline .

Thermal decomposition - Spectroscopic properties

\section{Introduction}

The alkaline earth metal chemistry has developed rapidly in the recent years due to their huge and versatile applications [1-5], especially in the relation to calcium and magnesium ions. The coordination chemistry and biochemical binding mechanisms of a magnesium ion $\mathrm{Mg}^{2+}$ are of special interest due to its significant role in biological processes [6-9]. For instance, at molecular level, these metal ions participate in homeostasis and are important in electrolyte pathophysiology [10]. Noteworthy is the fact that magnesium and its compounds are low toxic [11] and because of that they have many applications. Taking it into consideration, the investigations of coordination chemistry of this metal is crucial not only due to the need of biologically active magnesium compounds of clinical applications but they are also important in terms of obtaining new, environmentally and human friendly, materials of other usage. It is significant that the synthesis of such compounds should be possible simple and low-priced. The obtained compounds should be also thermal stable what is associated with conditions of medicine production processes. In addition, the thermal decomposition of magnesium coordination compounds commonly leads to nano-sized oxides and salts useful in various technical applications. As model ligands the hexamethylenetetramine (hmta) and 1,10-phenanthroline (phen) were chosen due to their specific properties: bulky shape and tetradentate donor function in case of hmta and rigid chelating function of phen. Hmta is a strong organic base that possesses four potential nitrogen donor atoms [12], is inexpensive, 
commercial available and has many applications ranging from the phenolic resins and their moulding compounds [13] to usage in medicine for treating of urinary tract infections [14]. Phen is a chelating bidentate ligand which is treated as a versatile starting material for organic and inorganic supramolecular chemistry $[15,16]$ and exhibits luminescence properties [17]. Both phen and hmta are used as model ligands for many bioactive molecules (including amino acids, proteins and nucleotides) due to possession of deshielded nitrogen atoms. Thus, some coordination aspects of presented magnesium complex compounds can be relevant in reference to other bioactive molecules. Noteworthy is the fact that phen and hmta containing compounds can exhibit far better properties (for example in case of phen luminescence) that the free ligands themselves. Concerning the above mentioned magnesium ion role and the need of materials of beneficial properties the magnesium sulphate complex compounds with hmta and phen were synthesised and studied, especially, in the matters of their thermal properties. The studying thermal properties (including stability and decomposition) are also important because the pharmacologically active compounds are used in medicine most commonly as solids and these solids are prepared at temperatures greater than ambient one [18]. These properties can also help to determine optimum conditions of compounds syntheses and define the parameters of technological processes. The obtained knowledge then can be also used to prevent the materials from the loss of specific physicochemical properties. It has to be mentioned that the structure of coordination compound of magnesium sulphate with phen is already known [19] but the investigations of this compound properties (thermal and spectroscopic), presented in this study, have not been reported.

\section{Experimental}

Materials and synthesis

All reagents (hexamethylenetetramine, 1,10-phenathroline, magnesium sulphate(VI) heptahydrate and ethanol) were analytical grade and they were obtained from POCh S.A. The magnesium sulphate(VI) complex compounds with hexemathylenetetramine (1) and 1,10-phenanthroline (2) were obtained in direct reaction between the salt and ligand. The samples of magnesium sulphate heptahydrate ( 0.2456 and $0.2465 \mathrm{~g}$, respectively, for $\mathbf{1}$ and 2) were dissolved in possible smallest amount of water $\left(5 \mathrm{~cm}^{3}\right)$ and then they were mixed with aqueous solution of hexamethylenetetramine (molar ratios 1:1 and 1:2) and alcohol ethyl solution of 1,10-phenanthroline (molar ratios 1:1 and 1:2), respectively, for $\mathbf{1}$ and $\mathbf{2}$. The mixtures were placed in a refrigerator and left to crystallize at $5{ }^{\circ} \mathrm{C}$. After 5 weeks the crystals were obtained, they were filtered and dried in air.

Crystal structure determination

Colourless prism shape crystals of $\mathbf{1}$ and $\mathbf{2}$ were mounted on a KM-4-CCD automatic diffractometer equipped with CCD detector, and used for data collection (graphite monochromated Mo $\mathrm{K}_{\alpha}$ radiation $(\lambda=0.71073 \AA)$, temperature 291.0(3) K, $\omega$ scan mode, the unit cells parameters based on 4084 (compound 1) and 6049 (compound 2) strong reflections, no observed loss of diffracted intensity during measurements). Lorentz, polarization, and numerical absorption [20] corrections were applied. The structures were solved by direct methods. All the non-hydrogen atoms were refined anisotropically using full-matrix, leastsquares technique on $F^{2}$. All the hydrogen atoms were found from difference Fourier synthesis after four cycles of anisotropic refinement, and refined as "riding" on the adjacent atom $\left[U_{\text {iso }}(\mathrm{H})=1.2 \quad U_{\text {eq }}(\mathrm{C})\right.$ and $U_{\text {iso }}(\mathrm{H})=1.5$ $\left.U_{\text {eq }}(\mathrm{O})\right]$. The carbon bonded hydrogen atom positions were

Table 1 Crystal data and structure refinement details for compound 1

\begin{tabular}{|c|c|}
\hline Compound & 1 \\
\hline Empirical formula & $\mathrm{C}_{12} \mathrm{H}_{46} \mathrm{MgN}_{8} \mathrm{O}_{15} \mathrm{~S}$ \\
\hline Formula weight & 598.94 \\
\hline Crystal system, space group & Triclinic, $P 1$ \\
\hline \multirow[t]{6}{*}{ Unit cell dimensions $/ \AA{ }^{\circ}{ }^{\circ}$} & $a=9.1478(7)$ \\
\hline & $b=9.4712(9)$ \\
\hline & $c=9.5956(8)$ \\
\hline & $\alpha=119.370(9)$ \\
\hline & $\beta=100.292(6)$ \\
\hline & $\gamma=97.934(7)$ \\
\hline Volume $/ \AA^{3}$ & $687.73(13)$ \\
\hline$Z$, Calculated density $/ \mathrm{Mg} / \mathrm{m}^{3}$ & $1,1.446$ \\
\hline Absorption coefficient $/ \mathrm{mm}^{-1}$ & 0.219 \\
\hline$F(000)$ & 322 \\
\hline Crystal size/mm & $0.289 \times 0.290 \times 0.261$ \\
\hline$\theta$ range for data collection $/^{\circ}$ & $3.38-25.10$ \\
\hline Index ranges & $\begin{array}{c}-10 \leq h \leq 10 \\
-11 \leq k \leq 11 \\
-11 \leq l \leq 11\end{array}$ \\
\hline Reflections collected/unique & $7301 / 4116\left(R_{(\mathrm{int})}=0.0213\right)$ \\
\hline Completeness & $99.6 \%$ to $\theta=25.10^{\circ}$ \\
\hline Min. and max. transmission & 0.930 and 0.948 \\
\hline Data/restraints/parameters & $4116 / 3 / 334$ \\
\hline Goodness-of-fit on $F^{2}$ & 1.077 \\
\hline Final $R$ indices $[I>2 \sigma(I)]$ & $R 1=0.0304, w R 2=0.0754$ \\
\hline$R$ indices (all data) & $R 1=0.0317, w R 2=0.0761$ \\
\hline Largest diff. peak and hole $\left(e \cdot \AA^{-3}\right)$ & 0.173 and -0.303 \\
\hline
\end{tabular}


Table 2 Selected structural data for studied compounds

\begin{tabular}{|c|c|c|}
\hline & $\begin{array}{l}\text { Structural } \\
\text { parameters/Å, }\end{array}$ & $\begin{array}{l}\text { Bond valences/ } \\
\text { v.u. }\end{array}$ \\
\hline \multicolumn{3}{|l|}{ Compound 1} \\
\hline $\mathrm{Mg} 1-\mathrm{O} 2$ & $2.0512(18)$ & 0.380 \\
\hline Mg1-O6 & $2.054(2)$ & 0.377 \\
\hline $\mathrm{Mg} 1-\mathrm{O} 3$ & $2.0619(17)$ & 0.369 \\
\hline $\mathrm{Mg} 1-\mathrm{O} 4$ & $2.0637(18)$ & 0.367 \\
\hline $\mathrm{Mg} 1-\mathrm{O} 1$ & $2.0684(17)$ & 0.363 \\
\hline Mg1-O5 & $2.1194(19)$ & 0.316 \\
\hline S11-O13 & $1.4691(17)$ & \\
\hline S11-O11 & $1.4722(19)$ & \\
\hline $\mathrm{S} 11-\mathrm{O} 14$ & $1.4756(19)$ & \\
\hline S11-O12 & $1.4800(19)$ & \\
\hline $\mathrm{O} 2-\mathrm{Mg} 1-\mathrm{O} 6$ & $93.80(8)$ & \\
\hline $\mathrm{O} 2-\mathrm{Mg} 1-\mathrm{O} 3$ & $91.81(7)$ & \\
\hline O6-Mg1-O3 & $92.45(8)$ & \\
\hline O2-Mg1-O4 & 179.43(9) & \\
\hline O6-Mg1-O4 & $86.56(8)$ & \\
\hline $\mathrm{O} 3-\mathrm{Mg} 1-\mathrm{O} 4$ & $87.73(7)$ & \\
\hline $\mathrm{O} 2-\mathrm{Mg} 1-\mathrm{O} 1$ & $87.84(7)$ & \\
\hline O6-Mg1-O1 & $89.32(8)$ & \\
\hline $\mathrm{O} 3-\mathrm{Mg} 1-\mathrm{O} 1$ & 178.21(9) & \\
\hline $\mathrm{O} 4-\mathrm{Mg} 1-\mathrm{O} 1$ & $92.61(7)$ & \\
\hline $\mathrm{O} 2-\mathrm{Mg} 1-\mathrm{O} 5$ & $88.73(8)$ & \\
\hline O6-Mg1-O5 & $176.45(9)$ & \\
\hline $\mathrm{O} 3-\mathrm{Mg} 1-\mathrm{O} 5$ & $89.95(7)$ & \\
\hline $\mathrm{O} 4-\mathrm{Mg} 1-\mathrm{O} 5$ & $90.93(8)$ & \\
\hline O1-Mg1-O5 & $88.29(7)$ & \\
\hline \multicolumn{3}{|l|}{ Compound 2} \\
\hline Mg2-O4 & $2.0374(16)$ & 0.394 \\
\hline $\mathrm{Mg} 2-\mathrm{O} 2$ & $2.0507(15)$ & 0.380 \\
\hline $\mathrm{Mg} 2-\mathrm{O} 3$ & $2.0539(15)$ & 0.377 \\
\hline Mg2-O1 & 2.0981(15) & 0.335 \\
\hline Mg2-N1 & $2.2205(17)$ & 0.367 \\
\hline Mg2-N2 & $2.2395(19)$ & 0.349 \\
\hline $\mathrm{S} 1-\mathrm{O} 7$ & $1.4564(15)$ & \\
\hline $\mathrm{S} 1-\mathrm{O} 4$ & $1.4707(14)$ & \\
\hline $\mathrm{S} 1-\mathrm{O} 5$ & $1.4730(14)$ & \\
\hline S1-O6 & $1.4999(15)$ & \\
\hline $\mathrm{O} 4-\mathrm{Mg} 2-\mathrm{O} 2$ & $95.54(6)$ & \\
\hline $\mathrm{O} 4-\mathrm{Mg} 2-\mathrm{O} 3$ & $102.08(7)$ & \\
\hline $\mathrm{O} 2-\mathrm{Mg} 2-\mathrm{O} 3$ & $85.14(6)$ & \\
\hline $\mathrm{O} 4-\mathrm{Mg} 2-\mathrm{O} 1$ & $88.36(6)$ & \\
\hline $\mathrm{O} 2-\mathrm{Mg} 2-\mathrm{O} 1$ & $174.34(7)$ & \\
\hline $\mathrm{O} 3-\mathrm{Mg} 2-\mathrm{O} 1$ & $90.05(6)$ & \\
\hline O4-Mg2-N1 & $90.51(7)$ & \\
\hline $\mathrm{O} 2-\mathrm{Mg} 2-\mathrm{N} 1$ & $86.76(6)$ & \\
\hline O3-Mg2-N1 & $165.62(7)$ & \\
\hline O1-Mg2-N1 & $97.32(6)$ & \\
\hline $\mathrm{O} 4-\mathrm{Mg} 2-\mathrm{N} 2$ & $162.63(7)$ & \\
\hline
\end{tabular}

Table 2 continued

\begin{tabular}{lll}
\hline & $\begin{array}{l}\text { Structural } \\
\text { parameters/Å, }\end{array}$ & $\begin{array}{l}\text { Bond valences/ } \\
\text { v.u. }\end{array}$ \\
\hline $\mathrm{O} 2-\mathrm{Mg} 2-\mathrm{N} 2$ & $92.84(7)$ & \\
$\mathrm{O} 3-\mathrm{Mg} 2-\mathrm{N} 2$ & $93.76(7)$ & \\
$\mathrm{O} 1-\mathrm{Mg} 2-\mathrm{N} 2$ & $84.50(6)$ & \\
$\mathrm{N} 1-\mathrm{Mg} 2-\mathrm{N} 2$ & $74.78(7)$ & \\
\hline
\end{tabular}

idealised after each cycle of refinement. The SHELXS97 [21], SHELXL97 [22] and SHELXTL [23] programs were used for all the calculations and were sources of atomic scattering factors. Details concerning crystal data and refinement are given in Table 1. Selected interatomic bond distances and angles are listed in Table 2, and geometrical parameters of intermolecular interactions are listed in Table 3. The determined structural parameters of $\mathbf{2}$ (empirical formula: $\mathrm{C}_{12} \mathrm{H}_{14} \mathrm{MgN}_{2} \mathrm{O}_{7} \mathrm{~S}$; crystal system: monoclinic; space group: $2{ }_{1} / c$; unit cell dimensions $\left(\AA,{ }^{\circ}\right): a=$ 12.0010(10), $b=10.0779(7), c=13.8536(10), \alpha=90.00$, $\beta=113.459(8), \quad \gamma=90.00 ;$ volume $\left(\AA^{3}\right): \quad 1537.0(2)$; reflections collected/unique: $15987 / 2735\left(\mathrm{R}_{(i n t)}=0.0512\right)$; data/restraints/parameters: 2735/0/214; GooF: 1.157; final $R$ indices $[I>2 \sigma(I)]: R 1=0.0393, w R 2=0.0884 ; R$ indices (all data): $R 1=0.0564, w R 2=0.0954$; largest diff. peak and hole $\left(\mathrm{e} \cdot \AA^{-3}\right): 0.254$ and -0.372$)$ were consistent with previously reported ones [19].

Physical measurement

The thermal analyses were carried out in a TG-DTA SETSYS-16/18 thermoanalyser coupled with ThermoStar (Balzers) mass spectrometer. The samples (10.7-11.63 mg) were heated in corundum crucibles up to $1000{ }^{\circ} \mathrm{C}$ at a heating rate $5{ }^{\circ} \mathrm{C} \mathrm{min}^{-1}$ in air and helium atmospheres. The products of the decomposition process were calculated from TG curves and the temperature ranges were determined by means of thermoanalyser Data Processing Module [24]. IR spectra of investigated complex compounds were recorded as $\mathrm{KBr}$ disc on Nicolet Magna 560 spectrophotometer over the range $4000-400 \mathrm{~cm}^{-1}$. The IR data are listed in Tables 4 and 5, respectively, for compounds 1 and 2. The UV-VIS spectra were recorded on Jasco V-660 spectrophotometer, in transmission mode, for solid samples pressed between two quartz plates. The absorption maxima are collected in Table 6. The two dimensional fluorescence spectra were recorded on Jasco FP-6500 spectrofluorimeter, with solid samples directed at the angle of $30^{\circ}$ to incident beam, and the data pitch and bandwith was $1 \mathrm{~nm}$ on both monochromators. The fluorescence maxima of compound $\mathbf{2}$ are gathered in Table 7 . The X-ray powder diffraction (XRPD) patterns were 
measured in reflection mode on an XPert PRO X-ray powder diffraction system equipped with a BraggBrentano PW 3050/65 high resolution goniometer and PW $3011 / 20$ proportional point detector. The $\mathrm{Cu} \mathrm{K} \alpha_{1}$ radiation was used. The patterns were measured at 291.0(2) $\mathrm{K}$ in the range $2^{\circ}-90^{\circ}$ with the narrowest beam attenuator. A diamond powder was used as an internal reference. The samples were sprinkled onto the sample holders using a small sieve, to avoid a preferred orientation. The thicknesses of the samples were no more than $0.1 \mathrm{~mm}$. During the measurements each specimen was spun in the specimen plane to improve particle statistics. Elemental analyses were carried out using Vario EL III CHNOS Elemental Analyzer (C, H, N, O). Magnesium content was determined by complexometric titration with the $0.01 \mathrm{~mol} / \mathrm{dm}^{3}$ water EDTA solution [25] and sulphur content was determined gravimetrically by precipitation of $\mathrm{BaSO}_{4}$ with $0.1 \mathrm{M}$ $\mathrm{BaCl}_{2}$ solution [26]. Analysis for complexes [calculated/ found (\%)]: (1) C 24.07/24.05, H 7.68/7.67, O 40.09/40.11,
N 18.72/18.68, S 5.36/5.29, Mg 4.06/4.08; (2) C 40.65/ 40.61, H 3.95/3.94, O 31.59/31.61, N 7.90,7.92 S 9.04/ 9.03, $\mathrm{Mg} 6.86 / 6.87$.

\section{Results and discussion}

\section{Crystal structure}

The complex compounds are air stable and well soluble in water. A perspective view of compounds $\mathbf{1}$ and $\mathbf{2}$ structures together with the atom numbering scheme is shown in Figs. 1 and 2, respectively. The structure of $\mathbf{1}$ consists of a complex cation $\left[\mathrm{Mg}\left(\mathrm{H}_{2} \mathrm{O}\right)_{6}\right]$, a sulphate(VI) anion, two hmta and water molecules assembled to the supramolecular network. The compound $\mathbf{2}$ is composed from neutral $\left[\mathrm{Mg}\left(\mathrm{H}_{2} \mathrm{O}\right)_{3}(\right.$ phen $\left.)\left(\mathrm{SO}_{4}\right)\right]$ complex molecules. Noteworthy is the fact that usage of 1:1 and 1:2 metal to ligand ratios in the syntheses leads to formation of complex compounds

Table 3 Hydrogen bonds in the studied compounds $\left(\AA 0^{\circ}\right)$

\begin{tabular}{|c|c|c|c|c|}
\hline $\mathrm{D}-\mathrm{H} \cdots \mathrm{A}$ & $\mathrm{d}(\mathrm{D}-\mathrm{H})$ & $\mathrm{d}(\mathrm{H} \cdots \mathrm{A})$ & $\mathrm{d}(\mathrm{D} \cdots \mathrm{A})$ & $<($ DHA $)$ \\
\hline \multicolumn{5}{|l|}{ Compound 1} \\
\hline $\mathrm{O} 1-\mathrm{H} 1 \mathrm{O} \cdots \mathrm{N} 14^{\mathrm{i}}$ & 0.88 & 1.98 & $2.844(3)$ & 170.7 \\
\hline $\mathrm{O} 1-\mathrm{H} 1 \mathrm{P} \cdots \mathrm{O} 11^{\mathrm{ii}}$ & 0.91 & 1.85 & $2.735(3)$ & 166.5 \\
\hline $\mathrm{O} 2-\mathrm{H} 2 \mathrm{O} \cdots \mathrm{O} 14^{\mathrm{iii}}$ & 0.95 & 1.74 & $2.691(2)$ & 175.5 \\
\hline $\mathrm{O} 2-\mathrm{H} 2 \mathrm{P} \cdots \mathrm{N} 2^{\mathrm{iv}}$ & 0.95 & 1.95 & $2.896(3)$ & 173.8 \\
\hline $\mathrm{O} 3-\mathrm{H} 3 \mathrm{O} \cdots \mathrm{O} 23^{\mathrm{v}}$ & 0.92 & 1.88 & $2.765(3)$ & 161.5 \\
\hline $\mathrm{O} 3-\mathrm{H} 3 \mathrm{P} \cdots \mathrm{N} 3^{\mathrm{v}}$ & 0.91 & 1.90 & $2.805(3)$ & 170.7 \\
\hline $\mathrm{O} 4-\mathrm{H} 4 \mathrm{O} \cdots \mathrm{O} 24$ & 0.90 & 1.85 & $2.721(3)$ & 162.2 \\
\hline O4-H4P $\cdots$ N11 & 0.87 & 2.02 & $2.892(3)$ & 176.1 \\
\hline $\mathrm{O} 5-\mathrm{H} 5 \mathrm{O} \cdots \mathrm{O} 13^{\mathrm{ii}}$ & 0.84 & 1.87 & $2.669(2)$ & 158.3 \\
\hline $\mathrm{O} 5-\mathrm{H} 5 \mathrm{P} \cdots \mathrm{N} 13^{\mathrm{ii}}$ & 0.91 & 1.97 & $2.877(3)$ & 172.2 \\
\hline $\mathrm{O} 6-\mathrm{H} 6 \mathrm{O} \cdots \mathrm{N} 4^{\mathrm{vi}}$ & 0.93 & 1.95 & $2.859(3)$ & 164.0 \\
\hline $\mathrm{O} 21-\mathrm{H} 21 \mathrm{O} \cdots \mathrm{N} 12$ & 0.90 & 2.06 & $2.940(3)$ & 164.5 \\
\hline $\mathrm{O} 21-\mathrm{H} 21 \mathrm{P} \cdots \mathrm{O} 12$ & 0.81 & 2.00 & $2.795(3)$ & 169.6 \\
\hline $\mathrm{O} 23-\mathrm{H} 23 \mathrm{O} \cdots \mathrm{O} 12$ & 0.85 & 2.02 & $2.853(3)$ & 167.9 \\
\hline $\mathrm{O} 23-\mathrm{H} 23 \mathrm{P} \cdots \mathrm{O} 25$ & 0.83 & 2.06 & $2.838(4)$ & 157.9 \\
\hline $\mathrm{O} 24-\mathrm{H} 24 \mathrm{P} \cdots \mathrm{O} 25$ & 0.80 & 2.22 & $2.973(3)$ & 158.6 \\
\hline $\mathrm{O} 25-\mathrm{H} 25 \mathrm{O} \cdots \mathrm{O} 11$ & 0.82 & 2.00 & $2.747(3)$ & 150.4 \\
\hline $\mathrm{C} 2-\mathrm{H} 2 \mathrm{~A} \cdots \mathrm{O} 21$ & 0.97 & 2.58 & $3.518(3)$ & 163.9 \\
\hline \multicolumn{5}{|l|}{ Compound 2} \\
\hline $\mathrm{O} 1-\mathrm{H} 1 \mathrm{~A} \cdots \mathrm{O} 7^{\mathrm{vii}}$ & 0.95 & 1.80 & $2.739(2)$ & 170.5 \\
\hline $\mathrm{O} 2-\mathrm{H} 2 \mathrm{~A} \cdots \mathrm{O}^{\mathrm{viii}}$ & 0.91 & 1.85 & $2.732(2)$ & 162.3 \\
\hline $\mathrm{O} 2-\mathrm{H} 2 \mathrm{~B} \cdots \mathrm{O} 5^{\mathrm{ix}}$ & 0.84 & 1.90 & $2.7366(19)$ & 170.4 \\
\hline $\mathrm{O} 3-\mathrm{H} 3 \mathrm{~A} \cdots \mathrm{O} 5^{\mathrm{viii}}$ & 0.85 & 1.98 & $2.813(2)$ & 165.8 \\
\hline $\mathrm{O} 3-\mathrm{H} 3 \mathrm{~B} \cdots \mathrm{O}^{\mathrm{vii}}$ & 0.91 & 1.85 & $2.752(2)$ & 171.1 \\
\hline $\mathrm{C} 10-\mathrm{H} 10 \cdots \mathrm{O}^{\mathrm{x}}$ & 0.93 & 2.31 & $3.187(3)$ & 156.7 \\
\hline
\end{tabular}

Symmetry transformations used to generate equivalent atoms: (i) $x, y+1, z$; (ii) $x, y, z-1$; (iii) $x+1, y, z-1$; (iv) $x+1, y+1, z$; (v) $x+1$, $y, z$; (vi) $x+1, y+1, z+1$; (vii) $-x+2,-y+1,-z+1$; (viii) $x,-0.5-y+2,-0.5+z+1$; (ix) $-x+2,-y+2,-z+1$; (x) $x-1$, $y, z$ 
Table 4 Vibrational frequencies $\left(\mathrm{cm}^{-1}\right)$ and their assignments for compound 1

\begin{tabular}{|c|c|c|c|}
\hline Compound 1 & Hmta [41, 42] & $\begin{array}{l}\text { Magnesium } \\
\text { sulphate [43-45] }\end{array}$ & Assignment \\
\hline $3467 \mathrm{w}$ & & & vas $\mathrm{O}-\mathrm{H}(\mathrm{H} 2 \mathrm{O})$ \\
\hline $3423 \mathrm{~m}$ & & & vas $\mathrm{O}-\mathrm{H}(\mathrm{H} 2 \mathrm{O})$ \\
\hline $2970 \mathrm{w}$ & 2966 & & $v \mathrm{CH}$ \\
\hline $2939 \mathrm{vw}$ & 2955 & & v $\mathrm{CH}$ \\
\hline $2892 \mathrm{w}$ & 2874 & & $v \mathrm{CH}$ \\
\hline 2199 vw & & & $\sigma \mathrm{O}-\mathrm{H}(\mathrm{H} 2 \mathrm{O})$ \\
\hline $2046 \mathrm{w}$ & & & $\sigma \mathrm{O}-\mathrm{H}(\mathrm{H} 2 \mathrm{O})$ \\
\hline $1682 \mathrm{~m}$ & & & $\delta \mathrm{O}-\mathrm{H}(\mathrm{H} 2 \mathrm{O})$ \\
\hline $1617 \mathrm{w}$ & & & $\delta \mathrm{O}-\mathrm{H}(\mathrm{H} 2 \mathrm{O})$ \\
\hline $1465 \mathrm{~s}$ & 1456 & & $\sigma \mathrm{CH}_{2}$ \\
\hline $1380 \mathrm{~s}$ & 1370 & & $\tau \mathrm{CH}_{2}$ \\
\hline 1240 vs & 1234 & & ${ }_{v} \mathrm{CN}$ \\
\hline $1182 \mathrm{~s}$ & & & $v \mathrm{SO}$ \\
\hline $1119 \mathrm{~s}$ & & 1115 & v $\mathrm{SO}$ \\
\hline $1054 \mathrm{w}$ & 1026 & & $v \mathrm{CN}$ \\
\hline 1007 vs & 1007 & & $v \mathrm{CN}$ \\
\hline $939 \mathrm{vw}$ & 925 & & v $\mathrm{N}-\mathrm{C}$ \\
\hline $815 \mathrm{w}$ & 825 & & $v \mathrm{~N}-\mathrm{C}$ \\
\hline $757 \mathrm{~m}+\mathrm{br}$ & 779 & & v $\mathrm{N}-\mathrm{C}$ \\
\hline $689 \mathrm{~s}$ & 673 & & $\delta \mathrm{N}-\mathrm{C}-\mathrm{N}$ \\
\hline $664 \mathrm{vw}$ & & & $\rho \mathrm{O}-\mathrm{H}(\mathrm{H} 2 \mathrm{O})$ \\
\hline $617 \mathrm{~s}$ & & 614 & $\delta \mathrm{SO}$ \\
\hline
\end{tabular}

Vibrations symbols: $v w$ very weak, $w$ weak, $m$ medium strength, $s$ strong, $v s$ very strong, $b r$ broadened, $v$ stretching, $\delta$ bending, $\tau$ wagging, $\rho$ rocking, $\sigma$ scissoring, as asymmetric

with one stoichiometry (1:2 and 1:1 ratio, respectively, for hmta and phen containing compound). All atoms in both compounds are located in general positions of the crystal net. The magnesium atoms are six coordinated and the coordination environment adopts the slightly distorted octahedral and distorted bipyramidal geometry [27], respectively, for 1 and 2 (Tables 2, 8; Fig. 3). The coordination environment of $\mathbf{1}$ is composed from six water molecules and of $\mathbf{2}$ from one chelating 2-phen molecule, three water molecules and one monodentate sulphate(VI) anion. The metal atom derives slightly from the polyhedron base in compound $\mathbf{1}$ and distinctly in compound $\mathbf{2}$ (Table 8). In both compounds, the polyhedra internal weighted least squares planes are inclined at angles close to the ideal $90^{\circ}$, but in 2 the distortion internal polyhedra polygons is distinctly grater than in $\mathbf{1}$ (Table 8 ). In case of consideration of the chelating phen ligand as monodendate one coordinating via bisectrix of $\mathrm{N}-\mathrm{Mg}-\mathrm{N}$ angle the coordination polyhedron of $\mathbf{2}$ can be described as a distorted trigonal bipyramid (Fig. 3c). The phen molecule can be considered as symmetrically bonded to the central atom
Table 5 Vibrational frequencies $\left(\mathrm{cm}^{-1}\right)$ and their assignments for compound 2

\begin{tabular}{|c|c|c|c|}
\hline Compound 2 & $\begin{array}{l}\text { Phen } \\
{[46,47]}\end{array}$ & $\begin{array}{l}\text { Magnesium } \\
\text { sulphate [43-45] }\end{array}$ & Assignment \\
\hline $3401 \mathrm{w}$ & & & $v \mathrm{O}-\mathrm{H}$ \\
\hline $3362 \mathrm{w}$ & & & $v \mathrm{O}-\mathrm{H}$ \\
\hline $2812 \mathrm{vw}$ & & & $v \mathrm{CH}$ \\
\hline $2727 \mathrm{vw}$ & & & $v \mathrm{CH}$ \\
\hline $2065 \mathrm{vw}$ & & & $\sigma \mathrm{O}-\mathrm{H}$ \\
\hline $1669 \mathrm{~m}$ & & & $\delta \mathrm{O}-\mathrm{H}$ \\
\hline $1624 \mathrm{~m}$ & & & $v \mathrm{CC}, v \mathrm{CN}$ \\
\hline $1515 \mathrm{~m}$ & & & $v \mathrm{CC}, v \mathrm{CN}$ \\
\hline $1497 \mathrm{w}$ & 1492 & & r CH \\
\hline $1424 \mathrm{~s}$ & 1420 & & $v \mathrm{CC}, v \mathrm{CN}, \delta-\mathrm{b} \mathrm{CH}$ \\
\hline $1379 \mathrm{vw}$ & & & $\mathrm{CC}, v \mathrm{CN}, \delta \mathrm{CH}$ \\
\hline $1370 \mathrm{vw}$ & & & $\mathrm{CC}, v \mathrm{CN}, \delta \mathrm{CH}$ \\
\hline $1222 \mathrm{w}$ & 1218 & & $\omega \mathrm{CH}$ \\
\hline $1146 \mathrm{w}$ & 1142 & & $\delta$-b CH \\
\hline $1102 \mathrm{w}+\mathrm{br}$ & 1096 & & $\delta-\mathrm{b} \mathrm{CH}$ \\
\hline $983 \mathrm{~m}$ & 996 & & ar breathing mode \\
\hline $865 \mathrm{w}$ & 855 & & $\omega \mathrm{CH}$ \\
\hline $840 \mathrm{~s}$ & 840 & & $\tau \mathrm{CH}$ \\
\hline $764 \mathrm{w}$ & 786 & & $\tau \mathrm{CH}$ \\
\hline $728 \mathrm{~s}$ & & & $\tau \mathrm{CH}$ \\
\hline $629 m+b r$ & 622 & 614 & $\rho$ ar, $\delta$ SO \\
\hline
\end{tabular}

Vibrations symbols: $v w$ very weak, $w$ weak, $m$ medium strength, $s$ strong, $v s$ very strong, $b r$ broadened, $v$ stretching, $\delta$ bending, $\tau$ wagging, $\omega$ twisting, $\rho$ rocking, $\sigma$ scissoring, ar aromatic ring

(Table 2) and a planar system (the maximum deviating atom C3 stick out $0.056(2) \AA$ form the weighted least squares plane calculated thought all non-hydrogen atoms of this ligand) and the magnesium ion derive 0.0999(17) $\AA$ form above mentioned plane. The sulphate(VI) anion in both compounds can be considered as fully delocalised (Table 2), however, in both cases one $\mathrm{S}-\mathrm{O}$ bond is slightly but clearly shorter and one longer than two others $\mathrm{S}-\mathrm{O}$ bonds.

The bond valences were computed as $v_{i j}=\exp \left[\left(R_{i j}-d_{i j}\right) /\right.$ $b]$ [28, 29], where $R_{i j}$ is the bond-valence parameter (in the formal sense $R_{i j}$ can be considered as a parameter equal to the idealised single-bond length between $i$ and $j$ atoms for given $b[30,31])$ and $b$ was taken as $0.37 \AA[32,33]$. The $R_{\mathrm{Mg}-\mathrm{O}}$ and $R_{\mathrm{Mg}-\mathrm{N}}$ were taken as 1.693 and 1.85 , respectively [33]. The computed bond valences are collected in Table 2. In both compounds all coordination bonds have the similar strength, nevertheless the bond is created by nitrogen or oxygen atom. Due to chelation, the phen molecules are bonded almost two times stronger than other ligands.

The hydrogen bonds present in the investigated compounds are shown in Table 3 . In compound $\mathbf{1}$, the following ones can be found: $\mathrm{O}-\mathrm{H} \cdots \mathrm{N}, \mathrm{O}-\mathrm{H} \cdots \mathrm{O}$, and 
Table 6 Absorption maxima and their molar coefficients for compound $\mathbf{2}$ and phen in water solutions and solid state

\begin{tabular}{|c|c|c|c|c|c|c|}
\hline \multirow[t]{3}{*}{ Maximum } & \multicolumn{3}{|c|}{ Compound 2} & \multicolumn{3}{|l|}{ Phen } \\
\hline & \multicolumn{2}{|c|}{ Water solution } & \multirow{2}{*}{$\begin{array}{l}\text { Solid state } \\
\lambda_{\max } \text { maximum } / \mathrm{nm}\end{array}$} & \multicolumn{2}{|c|}{ Water solution } & \multirow{2}{*}{$\begin{array}{l}\text { Solid state } \\
\lambda_{\max } / \mathrm{nm}\end{array}$} \\
\hline & $\lambda_{\max } / \mathrm{nm}$ & $e / \mathrm{dm}^{3} \mathrm{~cm}^{-1} \mathrm{~mol}^{-1}$ & & $\lambda_{\max } / \mathrm{nm}$ & $e / \mathrm{dm}^{3} \mathrm{~cm}^{-1} \mathrm{~mol}^{-1}$ & \\
\hline 1 & 200.4 & 335187.5 & & 200 & 353875 & \\
\hline 2 & 228.8 & 743750 & & 228.8 & 755000 & \\
\hline 3 & 264.9 & 541000 & 264.9 & 264.9 & 534375 & 252 \\
\hline 4 & 288 & 156250 & 293 & 290 & 156250 & 294 \\
\hline 5 & 310 & 21875 & & 310 & 18750 & \\
\hline 6 & 323.5 & 13397.5 & 326 & 323.5 & 12115 & 333 \\
\hline 7 & & & 519 & & & \\
\hline
\end{tabular}

Table 7 The UV-VIS fluorescence maxima of compounds 2

\begin{tabular}{llllllll}
\hline Compound & $\begin{array}{l}\text { Excitation } \\
\text { wavelength }\end{array}$ & $\begin{array}{l}\text { Emission } \\
\text { wavelength }\end{array}$ & $\begin{array}{l}\text { Relative } \\
\text { emission intensity }\end{array}$ & Compound & $\begin{array}{l}\text { Excitation } \\
\text { wavelength }\end{array}$ & $\begin{array}{l}\text { Emission } \\
\text { wavelength }\end{array}$ & $\begin{array}{l}\text { Relative } \\
\text { emission intensity }\end{array}$ \\
\hline $\mathbf{2}$ & 342 & 365 & 253.0 & Phen & 340 & 362 & 46.0 \\
& 342 & 382 & 232.0 & & 340 & 381 & 47.1 \\
\end{tabular}

Wavelengths are given in nanometre

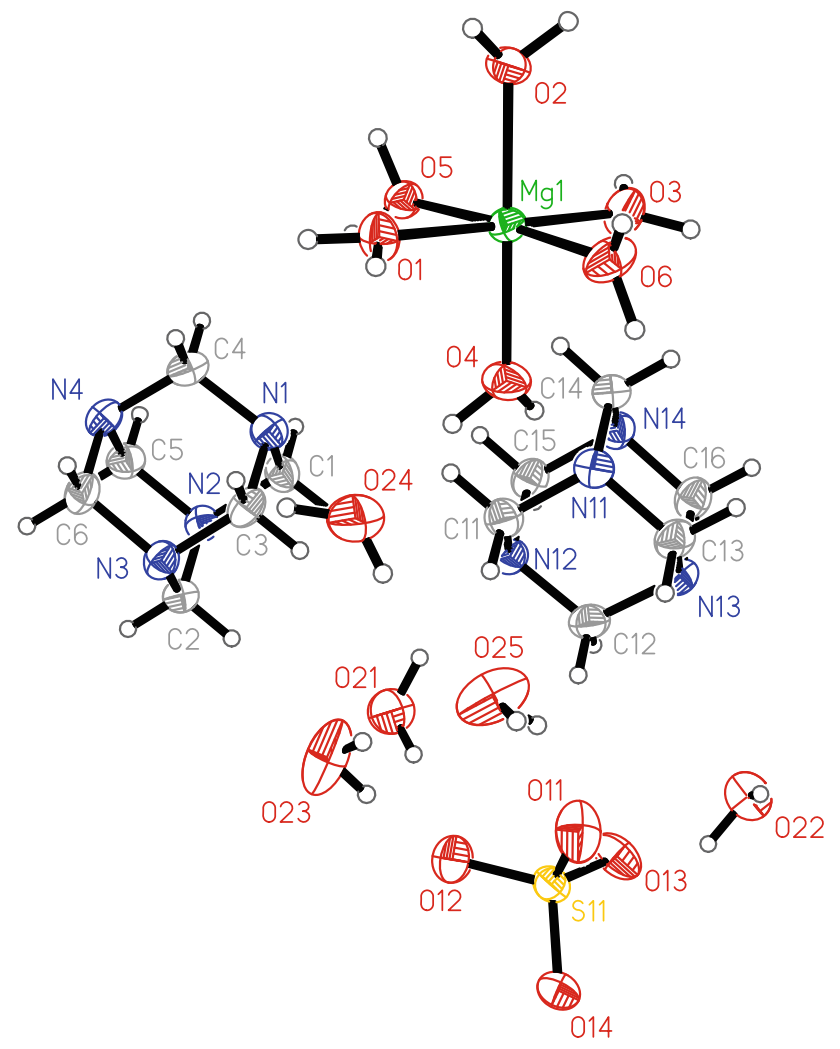

Fig. 1 The molecular conformation of compound 1 with atom numbering, plotted with $50 \%$ probability of displacement ellipsoids. The hydrogen atoms are drawn as the spheres of arbitrary radii

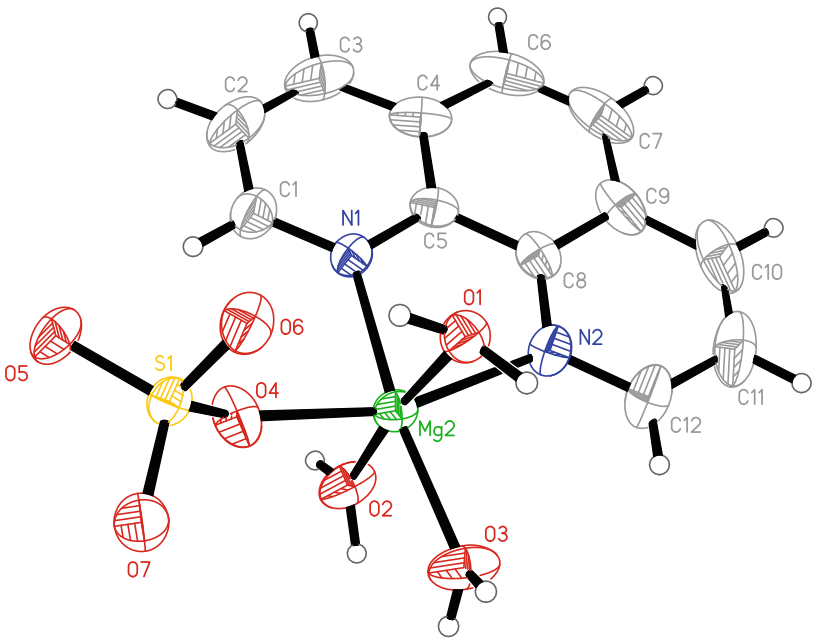

Fig. 2 The molecular conformation of compound 2 with atom numbering, plotted with $50 \%$ probability of displacement ellipsoids. The hydrogen atoms are drawn as the spheres of arbitrary radii

$\mathrm{C}-\mathrm{H} \cdots \mathrm{O}$. They are created between sulphate ion, water and hmta molecules and they are engaged in creating different graph sets $[34,35]$. Taking into consideration unitary graph set level, the only $\mathrm{D}$ patterns can be found in this compound. Chain and ring patterns $\left(\mathrm{C}_{2}^{2}(8)\right.$ and $\left.\mathrm{R}_{2}^{2}(8)\right)$ can be observed in the binary graph set. There are eight $\mathrm{N}_{2} \mathrm{C}_{2}^{2}(8)$ patterns and they are created by hydrogen bonds formed between magnesium-coordinated water and hmta 
Table 8 The dihedral angles between internal coordination polyhedra planes of compounds $\mathbf{1}$ and $\mathbf{2}$, together with deviation of the atoms from the weighted least squares planes

\begin{tabular}{|c|c|c|c|c|c|}
\hline Compound & Plane A & Plane B & $\begin{array}{l}\text { Dihedral angle } \\
\text { between planes } \\
\mathrm{A} \text { and } \mathrm{B} /{ }^{\circ}\end{array}$ & $\begin{array}{l}\text { Deviation of polyhedron } \\
\text { central atom } \\
\text { from plane } \mathrm{A} / \AA\end{array}$ & $\begin{array}{l}\text { Maximally deviating } \\
\text { atom from } \\
\text { plane } \mathrm{A} / \AA\end{array}$ \\
\hline \multirow[t]{3}{*}{1} & O1/O3/O5/O6 & $\mathrm{O} 1 / \mathrm{O} 3 / \mathrm{O} 2 / \mathrm{O} 4$ & $87.64(4)$ & $0.0214(13)$ & $\mathrm{O} 1,0.0268(10)$ \\
\hline & O1/O3/O2/O4 & $\mathrm{O} 2 / \mathrm{O} 4 / \mathrm{O} 5 / \mathrm{O} 6$ & $89.58(4)$ & $0.0189(14)$ & $\mathrm{O} 2$ and $\mathrm{O} 3,0.0128(10)$ \\
\hline & O2/O4/O5/O6 & O1/O3/O5/O6 & $87.80(4)$ & $0.0186(12)$ & $\mathrm{O} 4,0.0273(9)$ \\
\hline \multirow[t]{3}{*}{2} & $\mathrm{O} 1 / \mathrm{O} 2 / \mathrm{N} 2 / \mathrm{O} 4$ & $\mathrm{O} 1 / \mathrm{O} 2 / \mathrm{N} 1 / \mathrm{O} 3$ & $87.26(4)$ & $0.1018(10)$ & O1, 0.1964(8) \\
\hline & $\mathrm{O} 1 / \mathrm{O} 2 / \mathrm{N} 1 / \mathrm{O} 3$ & $\mathrm{~N} 1 / \mathrm{O} 3 / \mathrm{N} 2 / \mathrm{O} 4$ & $89.88(4)$ & $0.1438(10)$ & $\mathrm{O} 2,0.0871(8)$ \\
\hline & $\mathrm{N} 1 / \mathrm{O} 3 / \mathrm{N} 2 / \mathrm{O} 4$ & $\mathrm{O} 1 / \mathrm{O} 2 / \mathrm{N} 2 / \mathrm{O} 4$ & $89.09(3)$ & $0.0026(10)$ & $\mathrm{N} 1,0.1631(9)$ \\
\hline
\end{tabular}

Fig. 3 The magnesium coordination polyhedra in compound 1 (a) and $2(\mathbf{b}, \mathbf{c})$. The PHEN indicates the point located on crossing of $\mathrm{N} \cdots \mathrm{N}$ line segment with bisectrix of $\mathrm{N}-\mathrm{Mg}-\mathrm{N}$ angle (a)

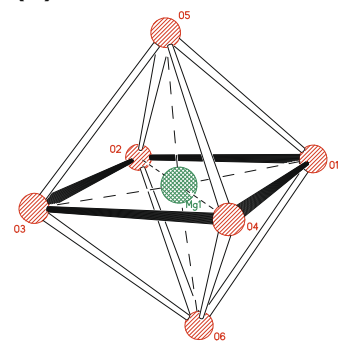

(b)

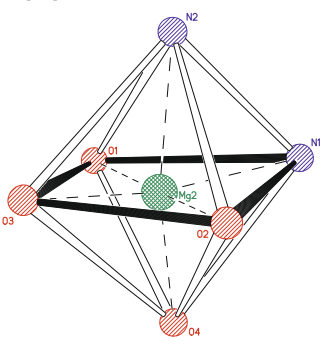

(c)

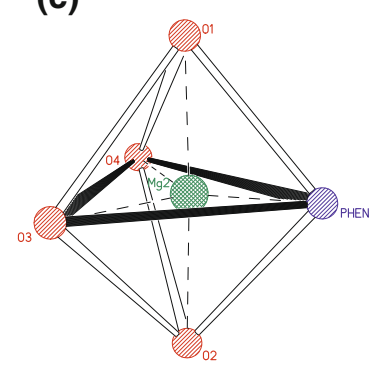

molecules (six patterns) and magnesium-coordinated water molecules and sulphate ions (two patterns). For example, relating to the first case-engaging hmta molecules-one of these patterns is created by $\mathrm{O} 1-\mathrm{H} 10 \cdots \mathrm{N} 14$ and $\mathrm{O} 4-$ $\mathrm{H} 4 \mathrm{P} \cdots \mathrm{N} 11$ hydrogen bonds. In the second case—engaging sulphate ion-one of the patterns is formed by $\mathrm{O} 1-$ $\mathrm{H} 1 \mathrm{P} \cdots \mathrm{O} 11$ and $\mathrm{O} 2-\mathrm{H} 2 \mathrm{O} \cdots \mathrm{O} 14$ hydrogen bonds. The sole $\mathrm{N}_{2} \mathrm{R}_{2}^{2}(8)$ pattern of compound $\mathbf{1}$ is created by hydrogen bonds present between magnesium-coordinated water molecules and sulphate ions and it contains O1-H1P...O 11 and $\mathrm{O} 5-\mathrm{H} 5 \mathrm{O} \cdots \mathrm{O} 13$ hydrogen bonds. Unitary graph set level of 2 is created by $C_{1}^{1}(6) C_{1}^{1}(6) R_{2}^{2}(12) R_{2}^{2}(12) R_{2}^{2}(12)$ motifs utilizing $\mathrm{O}-\mathrm{H} \cdots \mathrm{O}$ hydrogen bonds and $\mathrm{C}_{1}^{1}(9)$ motifs of lowest degree formed by $\mathrm{C}-\mathrm{H} \cdots \mathrm{O}$ hydrogen bonds (Table 3). Both $\mathrm{N}_{1} \mathrm{C}_{1}^{1}(6)$ and $\mathrm{N}_{1} \mathrm{R}_{2}^{2}(12)$ patterns are patterns formed by hydrogen bonds present between magnesiumcoordinated water molecules and magnesium coordinated sulphate ion and these can be for example the O1-H1B $\cdots \mathrm{O} 6$ hydrogen bond $\left(\mathrm{N}_{1} \mathrm{C}_{1}^{1}(6)\right.$ pattern) and O1-H1A $\cdots$ O 7 hydrogen bond $\left(\mathrm{N}_{1} \mathrm{R}_{2}^{2}(12)\right.$ pattern).

The thermal decomposition

The thermal decomposition of the studied compounds is a gradual process (Scheme 1). The thermoanalytical curves TG-DTA and DTG of $\mathbf{1}$ are presented in Fig. 4. It can be noticed that it is a rapid and multi-stage process. The first endothermic step occurs within temperature range
$45-175{ }^{\circ} \mathrm{C}$. Within this temperature range, three individual steps can be distinguished and the mass loss is attributed to removal of water molecules. The next stage is the sublimation and decomposition of hmta [36]. This step is indicated by a strong, narrow peak on the DTA and DTG curves. The biggest mass loss is observed and the mass spectrum of the thermal decomposition, as the temperature rises, shows the replacement of hmta ion current signal $\mathrm{m} /$ $z=140$ by $m / z=30,44$ which correspond to $\mathrm{NO}^{+}$, $\mathrm{HCOH}^{+}$and $\mathrm{CO}_{2}^{+}$species, what is explained by combustion of non-sublimated hmta molecules. The removal of hmta finishes at about temperature of $600{ }^{\circ} \mathrm{C}$ and the solid product is $\mathrm{MgSO}_{4}$. The thermal decomposition of $\mathbf{1}$ in helium atmosphere is different. The decomposition process begins at about temperature of $45^{\circ} \mathrm{C}$. The first steps are the endothermic processes which correspond to removal of water molecules. At about temperature of $145^{\circ} \mathrm{C}$ the further decomposition begins. The remained water molecules are removed and the hmta elimination and sulphate ion decomposition process starts. It is impossible to distinguish individual steps of these processes. It has to be noted that the hmta removal is an endothermic process and it is first associated with the sublimation of their molecules, but as the temperature rises the mass spectrum of the thermal decomposition shows ion current signals $m / z=12,30$ and 44 which corresponds to the molecular mass of $\mathrm{C}^{+}, \mathrm{NO}^{+}$ and $\mathrm{HCOH}^{+}$and $\mathrm{CO}_{2}{ }^{+}$. Thus, it is stated that some of the hmta molecules undergo a combustion process and the 
(a)
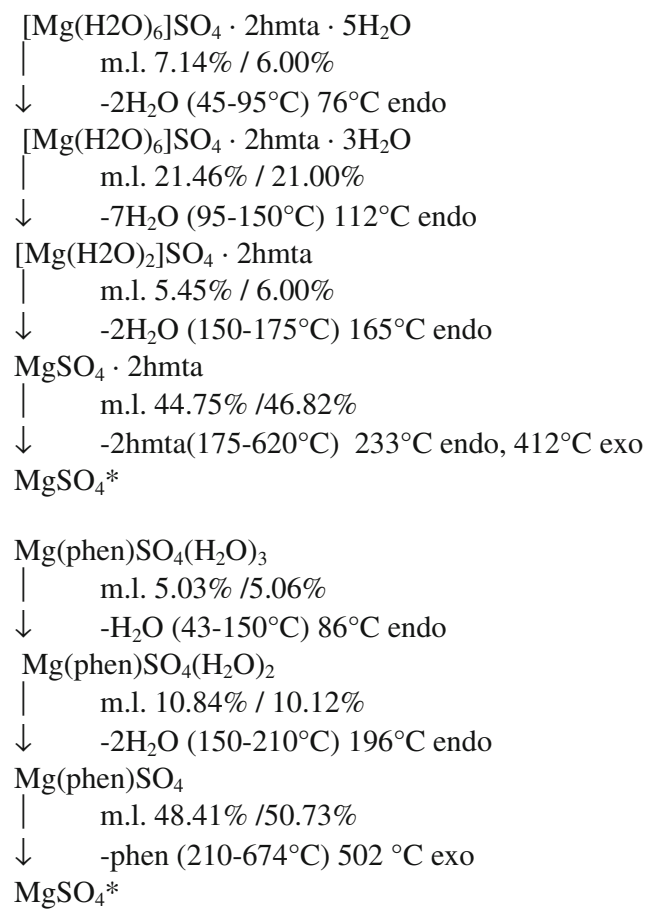

\section{(b)}
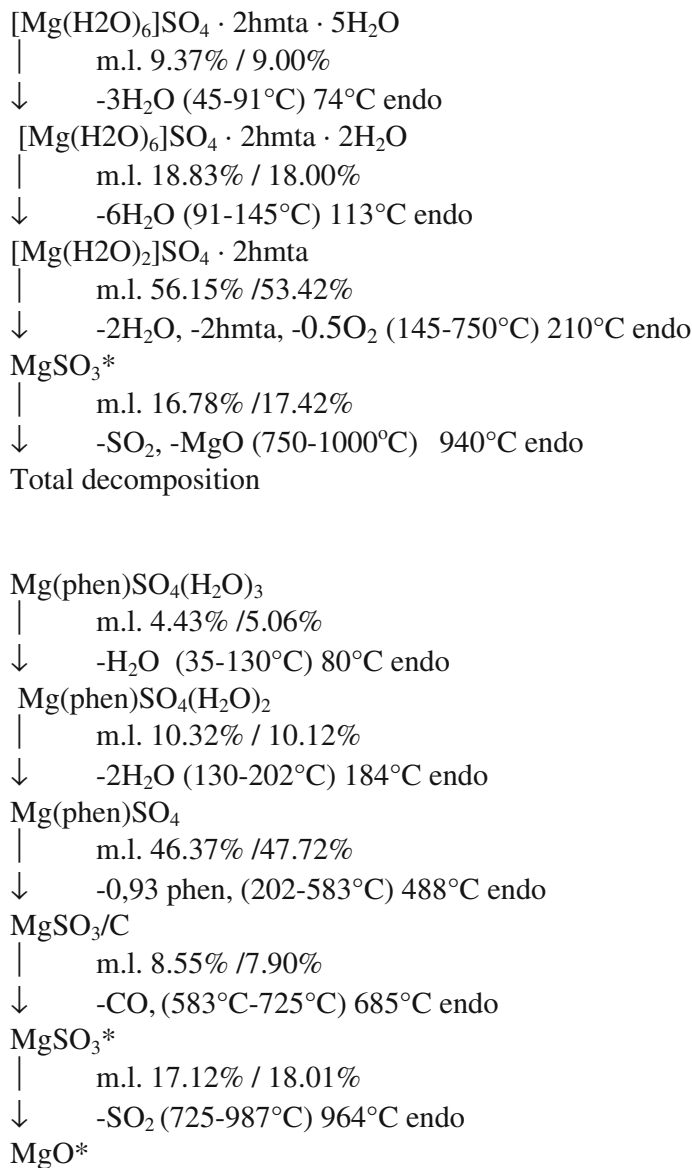

४ Scheme 1 Stages of the thermal decomposition of the studied compounds in air (a) and helium (b) atmosphere, m.l. experimental mass loss/theoretical mass loss, asterisk product was confirmed by XRPD

needed oxygen comes from decomposition of the sulphate(VI) ion - the ion current shows a faint signal which corresponds to the molecular mass of $\mathrm{O}^{+}(\mathrm{m} / z=16)$. This process finishes at about temperature of $750{ }^{\circ} \mathrm{C}$ and the solid product is $\mathrm{MgSO}_{3}$ which quickly decomposes to sulphur dioxide (the mass spectrum displays the presence of $\mathrm{SO}_{2}{ }^{+}(\mathrm{m} / \mathrm{z}=64)$ and $\left.\mathrm{SO}^{+}(\mathrm{m} / \mathrm{z}=48)\right)$ and magnesium oxide (which is removed during further heating probably due to formation of nanosized and smaller volatile particles).

Compound 2 decomposes in several steps, both in air and in helium atmosphere (Scheme 1). The process is not as rapid as in the case of compound $\mathbf{1}$ (probably due to the presence of chelating phen molecule strongly bonded to the magnesium ion). In air, the decomposition process begins at about temperature of $43{ }^{\circ} \mathrm{C}$. The first two steps are related to removal of water molecules (temperature range $43-210{ }^{\circ} \mathrm{C}$ ). When the temperature reaches about $210^{\circ} \mathrm{C}$ the decomposition of phen begins. It is a complex stage
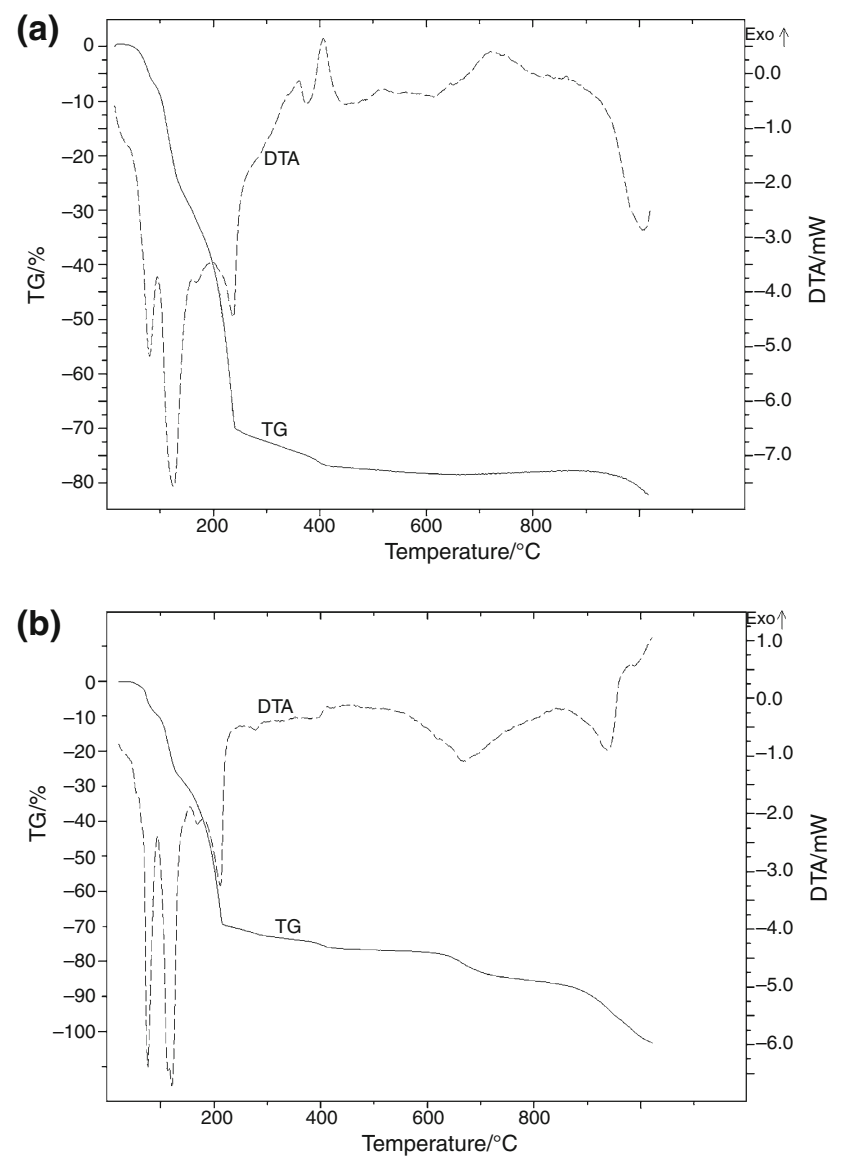

Fig. 4 TG, DTG and DTA curves of compound $\mathbf{1}$ in air (a) and in helium (b) atmosphere 

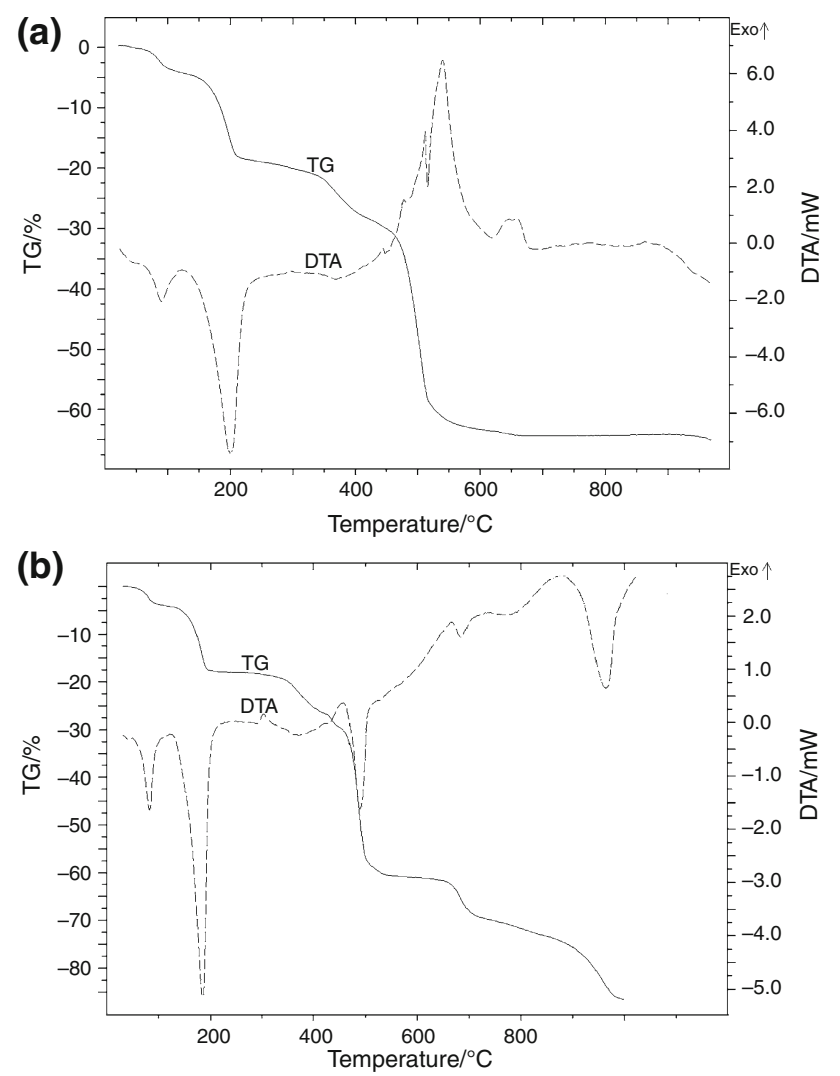

Fig. 5 TG, DTG and DTA curves of compound 2 in air (a) and in helium (b) atmosphere

which partially covers with the previous one-removal of the water molecules. It is an exothermic combustion process and it is indicated by a strong, narrow peak on the DTA and DTG curves (Fig. 5a) accompanied by the biggest mass loss and the presence of ion current signals $\mathrm{m} / \mathrm{z}=30$ and 44 in the mass spectrum, corresponding to the $\mathrm{NO}^{+}$and $\mathrm{CO}_{2}{ }^{+}$species, respectively. At temperature of about $674{ }^{\circ} \mathrm{C}$ the combustion of phen finishes and the remaining solid product is $\mathrm{MgSO}_{4}$. In helium atmosphere the compound 2 is stable up to temperature of about $35^{\circ} \mathrm{C}$. The first step is removal of water molecules (Scheme 1) as it was observed during the decomposition in air. Then, at temperature of about $202{ }^{\circ} \mathrm{C}$, removal of phen is observed, and this process is getting faster when the temperature rises (Fig. 5b). It is an endothermic one and it is associated with sublimation of the ligand and its partial carbonization. Then, the remaining carbon undergoes an oxidation-the mass spectrum shows the presence of ion current signals $(\mathrm{m} / \mathrm{z}=12,16,28$ and 44) which correspond to the molecular mass of $\mathrm{C}^{+}, \mathrm{O}^{+}, \mathrm{CO}^{+}$and $\mathrm{CO}_{2}{ }^{+}$, respectively. The oxygen utilized in this stage comes from the decomposition of the sulphate(VI) ion which occurs in the same temperature range. The last observed step is removal of $\mathrm{SO}_{2}$ (the mass spectrum shows the presence of $\mathrm{SO}_{2}{ }^{+}$ $(\mathrm{m} / \mathrm{z}=64))$ and formation of $\mathrm{MgO}$. At the measurement range upper limit $\left(1000^{\circ} \mathrm{C}\right)$ the decomposition process is not finished and the TG curve is inclined at the small angle to the constant mass line, thus it can be supposed that on further heating the $\mathrm{MgO}$ would be removed similarly to the process observed for the decomposition of compound $\mathbf{1}$ in helium atmosphere.

\section{Spectroscopy}

Due to the absence of chromophores, the spectrum of $\mathbf{1}$ does not show any absorption maxima in the investigated region of electromagnetic spectrum. The spectrum of $\mathbf{2}$ in a water solution exhibits six absorption maxima (Table 6) similarly to the water solution of phen (Table 6). The first three maxima are attributed to $\pi \rightarrow \pi^{*}$ transitions [37], which are typical for compounds containing an aromatic ring-the optical spectrum of benzene exhibits three absorption maxima at 180, 200 and $255 \mathrm{~nm}$ [38]. In the protonated phenantroline (phenH) the last three maxima are distinctly weakened and faintly exist (especially maximum at $312 \mathrm{~nm}$ ), and additionally they are significantly red shifted [39]. Because the protonation of phen leads to utilisation of lone electron pair of one $\mathrm{N}$ atom for creation of the $\mathrm{N}-\mathrm{H}$ bond and second atom creates the $\mathrm{N} \cdots \mathrm{H}-\mathrm{N}$ hydrogen bond via its electron pair [40] thus, these last three maxima can be attributed to $n \rightarrow \pi^{*}$ transitions (diminished in phenH by more rigid and less delocalised free electron pair). In comparison to the phen, in a water solution the $\pi \rightarrow \pi^{*}$ transitions in $\mathbf{2}$ are slightly weakened (apart from one at $264.9 \mathrm{~nm}$ ) whilst the $n \rightarrow \pi^{*}$ transitions are faintly stronger (Table 6). This suggests that in the solution the $\mathbf{2}$ is considerably dissociated and the phen molecule exists mainly in uncomplexed form. Solid state spectrum of $\mathbf{2}$ exhibits less maxima in comparison to the spectrum in a water solution (Table 6) and it can originate from both partial overlapping (and thus disappearance) of weak absorption maxima with strong ones and shift of most energetic maxima beyond the measurement range. The last maxima observed in VIS range (at $519 \mathrm{~nm}$ ) can be attributed to charge transfer $\mathrm{L} \rightarrow \mathrm{M}$ transitions between the $\pi$ orbital of phen and the magnesium ion. The solid state spectrum of phen exhibits three maxima (Table 6) originating from $\pi \rightarrow \pi^{*}$ (at $252 \mathrm{~nm}$ ) and $n \rightarrow \pi^{*}$ transitions (at 294 and $333 \mathrm{~nm}$ ). The $\pi \rightarrow \pi^{*}$ transition of phen is more energetic than of $\mathbf{2}$ due to $\pi \cdots \pi$ stacking interactions appearing in pure phen (absent in $\mathbf{2}$ ).

Due to the nature of the metal ion and the ligand, the $\mathbf{1}$ does not show fluorescence properties. The two dimensional fluorescence spectrum of $\mathbf{2}$ (Fig. 6) shows that this compound is an effective fluorescent material in solid state, with the much stronger emission (about five times) than the pure ligand (Table 7). The solid state fluorescence spectrum of phen (Fig. 6a) shows three emission maxima. The 

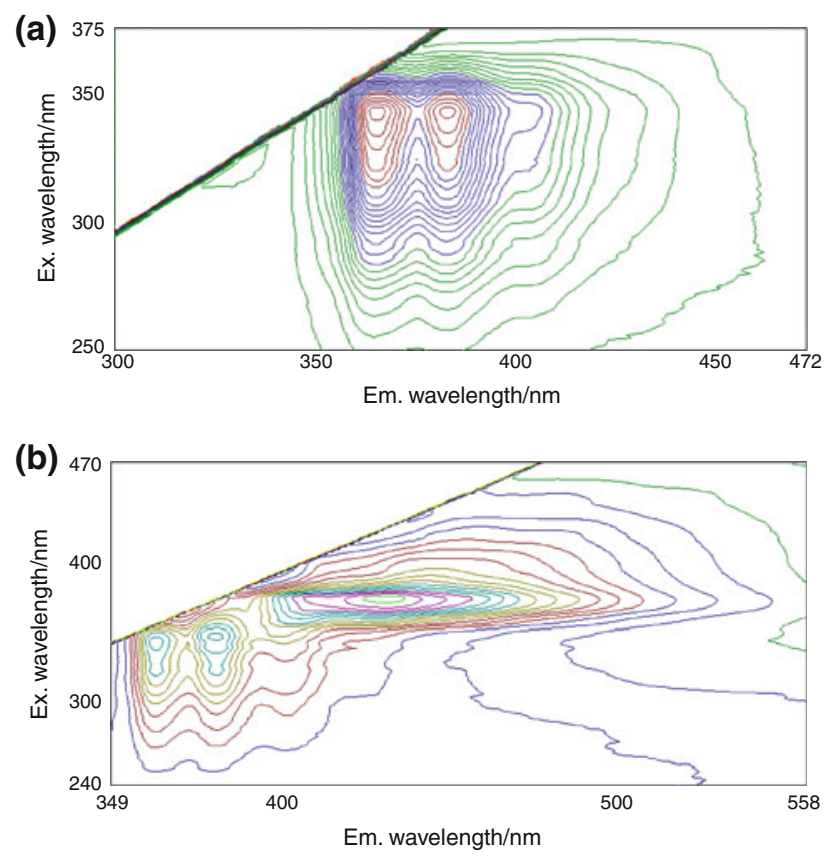

Fig. 6 The two dimensional fluorescence spectra of the compound 2 (a) and phen (b). The contour intervals are 10 intensity units for $\mathbf{2}$ and 4 intensity units for phen

two first maxima appear at the same excitation wavelength, $340 \mathrm{~nm}$, whilst the last one at $370 \mathrm{~nm}$ excitation wavelength. The complexation leads not only to the changes of intensities but it also causes changes in the excitation/ emission characteristic (Fig. 6b). The excitation and emission wavelengths of two first maxima of $\mathbf{2}$ are slightly shifted to lower energies but their emission distinctly increases (Table 7) and third emission maximum existing in phen is absent in $\mathbf{2}$ (Table 7).

\section{IR spectra}

The IR spectra of compound 1 (Fig. 7) and 2 (Fig. 8) exhibit bands typical for water molecules with bending $\mathrm{OH}$ vibration in range $1617-1682 \mathrm{~cm}^{-1}$, OH scissoring vibrations varying from 2046 to $2199 \mathrm{~cm}^{-1}$ and $\mathrm{OH}$ stretching vibrations in range $3362-3423 \mathrm{~cm}^{-1}$. The spectrum of 1 exhibits strong bands assigned to hmta molecules at 1465 , 1380 and $1240 \mathrm{~cm}^{-1}$ and they are shifted towards higher frequencies in comparison to pure hmta [41, 42] (Table 4). These shifts are caused by $\mathrm{O}-\mathrm{H} \cdots \mathrm{N}$ and $\mathrm{C}-\mathrm{H} \cdots \mathrm{O}$ hydrogen bonds connecting the hmta molecules with other molecular and ionic species in $\mathbf{1}$ (Table 3). The two strong SO stretching and one strong SO bending vibrations of $\mathrm{SO}_{4}{ }^{2-}$ ion at 1119,1182 and $617 \mathrm{~cm}^{-1}$, respectively [43] are slightly shifted towards higher frequencies (in comparison to pure $\mathrm{MgSO}_{4}$ [44]) due to creation of $\mathrm{O}-\mathrm{H} \cdots \mathrm{O}$ hydrogen bonds (Table 3 ). The multifurcating of the sulphate ion oxygen atoms acting as a hydrogen bond acceptor leads to duplication of $\mathrm{SO}$ stretching vibration of $\mathbf{1}$ in comparison to the pure $\mathrm{MgSO}_{4}$ [44] (Table 4). The IR spectrum of compound $\mathbf{2}$ is more complex than superimposition of spectra of individual ligands (Table 5). In the compound 2, the amine exhibits shifts of some vibrations modes to higher frequencies in comparison to the free ligand (e.g., $\mathrm{CC}$ and $\mathrm{CN}$ stretching modes, Table 5), typical for chelating phen located in the inner coordination sphere. The complexation leads also to the shift of some vibrations
Fig. 7 IR spectrum of compound 1

Fig. 8 IR spectrum of compound 2
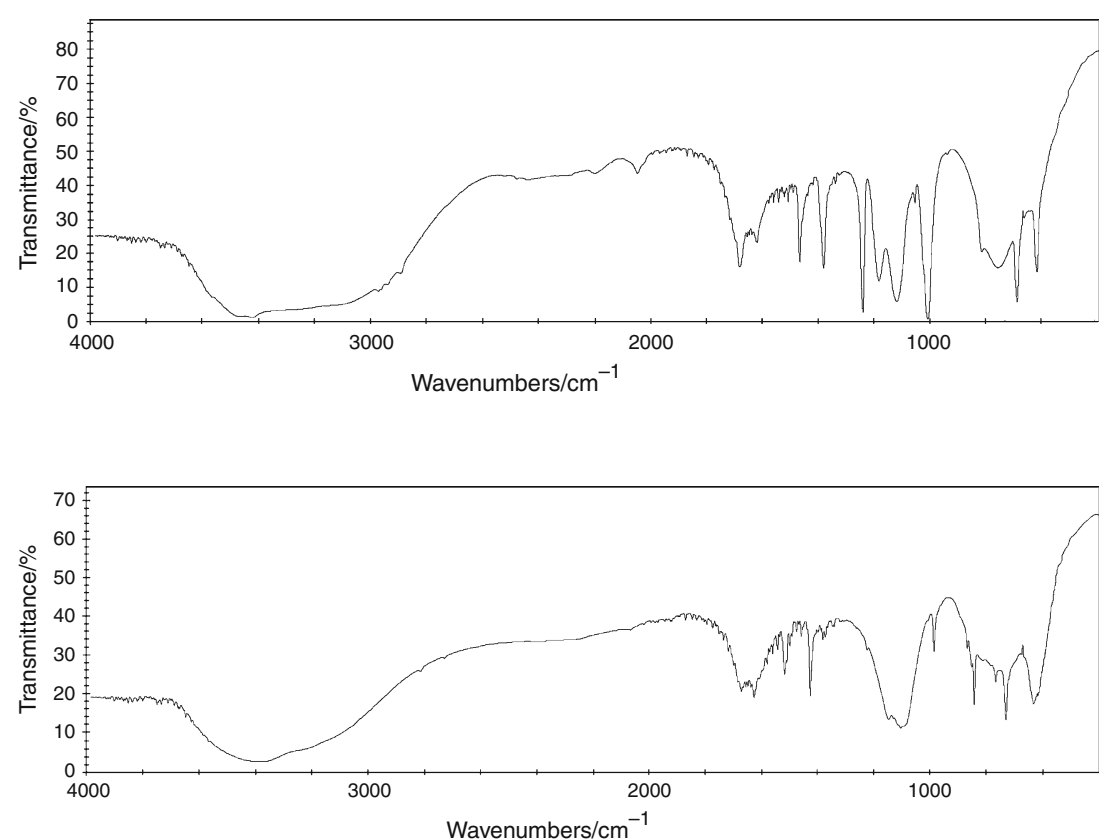
of phen to lower frequencies (e.g., aromatic breathing mode vibrations at $983 \mathrm{~cm}^{-1}$ or $\mathrm{CH}$ wagging vibrations at $764 \mathrm{~cm}^{-1}$ ) due to formation of rigid five-membered chelating ring and in consequence decreasing of aromatic rings oscillators energy. The weakening of these oscillators partially also originates from creation of $\mathrm{C}-\mathrm{H} \cdots \mathrm{O}$ hydrogen bonds (Table 3) and in consequence decreasing of phenantoline atoms mobility. The SO stretching vibrations appearing clearly in spectra of compound $\mathbf{1}$ do not exist in spectra of compound $\mathbf{2}$ due to restraining of anion vibrational freedom by complexation to metal cation in $\mathbf{2}$.

\section{Conclusions}

The studied compounds possess different placement of the amine ligands: in outer and inner coordination sphere, respectively, for $\mathbf{1}$ and $\mathbf{2}$. Besides the differences between the amines themselves, their locations affect both the thermal and spectral properties. The $\mathbf{1}$ and $\mathbf{2}$ decompose differently in air and helium atmospheres and the final products of their decompositions are different in each gas-in helium atmosphere the sulphate ion of the $\mathbf{1}$ and $\mathbf{2}$ undergoes decomposing what does not take place in air atmosphere. The decomposition of $\mathbf{1}$ in both studied atmospheres is rapid whilst $\mathbf{2}$ decomposes more slowly. The UV-VIS absorption spectrum of $\mathbf{2}$ shows six maxima in a water solution and they are attributed to $\pi \rightarrow \pi^{*}$ (the three more energetic) and $n \rightarrow \pi^{*}$ (the three less energetic) transitions whilst its solid state spectrum exhibits only four maxima due to weakening and shifting of some maxima. The fluorescence solid state study of $\mathbf{2}$ shows that this compound is a potent fluorescence material.

\section{Supplementary data}

Tables of crystal data and structure refinement, anisotropic displacement coefficients, atomic coordinates and equivalent isotropic displacement parameters for non-hydrogen atoms, H-atom coordinates and isotropic displacement parameters, bond lengths and interbond angles have been deposited with the Cambridge Crystallographic Data Centre under Nos. CCDC813464 and CCDC813465, respectively, for $\mathbf{1}$ and $\mathbf{2}$.

\begin{abstract}
Acknowledgements This study was financed by funds allocated by the Ministry of Science and Higher Education to the Institute of General and Ecological Chemistry, Technical University of Lodz.
\end{abstract}

Open Access This article is distributed under the terms of the Creative Commons Attribution Noncommercial License which permits any noncommercial use, distribution, and reproduction in any medium, provided the original author(s) and source are credited.

\section{References}

1. Chi Y, Ranjan S, Chung PW, Hsieh HY, Peng SM, Lee GH. Alkaline-earth metal fluoroalkoxide complexes with multi-coordinated polyether appendage: synthesis and characterization. Inorg Chim Acta. 2002;334:172-82.

2. Botana L, Bastida R, Macías A, Pérez-Lourido P, Valencia L. Alkali and alkaline-earth metal complexes of different nuclearities with azamacrocyclic pendant-arms ligands. Inorg Chim Acta. 2009;362:3351-6.

3. Mojumdar SC, Madgurambal G, Saleh MT. A study on synthesis and thermal, spectral and biological properties of carboxylato$\mathrm{Mg}(\mathrm{II})$ and carboxylato- $\mathrm{Cu}(\mathrm{II})$ complexes with bioactive ligands. J Therm Anal Calorim. 2005;81:205-10.

4. Wieczorek-Ciurowa K, Dulian P, Nosal A, Domagała J. Effects of reagents' nature on mechanochemical synthesis of calcium titanate. J Therm Anal Calorim. 2010;101:471-7.

5. Luan SR, Zhu YH, Jia YQ. Alanine- and taurine-salicylal Schiff base complexes of magnesium. Synthesis, characterization and thermal decomposition. J Therm Anal Calorim. 2009; 95:951-6.

6. Neykova M, Almsick T, Dimitrov G. Synthesis, spectral properties and crystal structure of calcium and strontium complexes of 1,10-phenanthroline. Z Anorg Allg Chem. 2006;632:1554-9.

7. Carugo O, Djunovic K, Rizzi MJ. Comparison of the co-ordinative behaviour of calcium(II) and magnesium(II) from crystallographic data. J Chem Soc Dalton Trans. 1993;14:2127-35.

8. Rezaei Behbehani G, Saboury AA. A thermodynamic study on the binding of magnesium with human growth hormone. Consideration of the new extended coordination model solvation parameters. J Therm Anal Calorim. 2007;89:857-61.

9. Frakes MA, Richardson LE. Magnesium sulfate therapy in certain emergency conditions. Am J Emerg Med. 1997;15:182-7.

10. Radford Shanklin D. Cellular magnesium acquisition: an anomaly in embryonic cation homeostasis. Exp Mol Pathol. 2007;83(83):224-40.

11. Muir KW. Therapeutic potential of magnesium in the treatment of acute stroke. J Stroke Cerebrovasc Dis. 2000;9:257-67.

12. Agwara MO, Ndifon PT, Ndikontar MK. Physicochemecal studies of some hexamethylenetetramine metal(II) complexes. Bull Chem Soc Ethiop. 2004;18:143-8.

13. Pizzi A, Kueny R, Lecoanet F, Massetau B, Carpentier D, Krebs A, Loiseau F, Molina S, Ragoubi M. High resin content natural matrix-natural fibre biocomposites. Ind Crop Prod. 2009;30: 235-40.

14. Greenwood D, Slack RCB. The antibacterial activity of hexamine (methenamine), hexamine hippurate and hexamine mandelate. Infection. 1981;9:223-7.

15. Bencini A, Lippolis V. 1,10-Phenanthroline: a versatile building block for the construction of ligands for various purposes. Coord Chem Rev. 2010;254:2096-180.

16. Meenakshisundaram SP, Parthiban S, Kalavathy R, Madhurambal G, Bhagavannarayana G, Mojumdar SC. Thermal and optical properties of ZTS single crystals in the presence of 1,10-phenanthroline (Phen). Crystalline perfection studies. J Therm Anal Calorim. 2010;100:831-7.

17. Armaroli N, De Cola L, Balzani V, Sauvage JP, Dietrich-Buchecker DO, Kern JM. Absorption and luminescence properties of 1,10-phenanthroline, 2,9-diphenyl-1,10-phenanthroline, 2,9dianisyl-1,10-phenanthroline and their protonated forms in dichloromethane solution. J Chem Soc Faraday Trans. 1992;88: $553-6$.

18. Szynkaruk P, Wesolowski M, Samson-Rosa M. Principal component analysis of thermal decomposition of magnesium salts used as drugs. J Therm Anal Calorim. 2010;101:505-12. 
19. Zhu L, Huang J, Han S, An Z. mer-Triaqua(1,10-phenanthroline$\left.\kappa 2 \mathrm{~N}, \mathrm{~N}^{\prime}\right)($ sulfato- $\kappa \mathrm{O})$ magnesium(II). Acta Cryst E. 2008;64:683.

20. X-RED. Version 1.18. STOE \& Cie GmbH, Darmstadt, Germany (1999).

21. Sheldrick GM. Phase annealing in SHELX-90: direct methods for larger structures. Acta Cryst A. 1990;46:467-73.

22. Sheldrick GM. SHELXL97. Program for the solution and refinement of crystal structures. University of Gottingen, Germany (1997).

23. Sheldrick GM. SHELXTL: release 4.1 for Siemens Crystallographic Research Systems (1990).

24. Data Processing Module. Copyright ${ }^{\odot}$ 1994-1998 SETARAM, France; Version 1.4.

25. Welcher FJ. The analytical uses of etylenediamineteraacetic acid. Warsaw: WNT; 1963.

26. Lipiec T, Szmal ZS. Analytical chemistry with instrumental analysis elements. Warsaw: PZWL; 1976.

27. Kepert DL. Aspects of the stereochemiastry of six-coordination. In: Lippard SJ, editor. Progress in inorganic chemistry, vol 23. New York: Wiley; 1977.

28. Zachariasen WH. Bond lengths in oxygen and halogen compounds of $d$ and $f$ elements. J Less Common Met. 1978;62:1-7.

29. Brown ID. Influence of chemical and spatial constraints on the structures of inorganic compounds. Acta Crystallogr B. 1997;53: 381-93.

30. Trzesowska A, Kruszynski R, Bartczak TJ. New bond-valence parameters for lanthanides. Acta Crystallogr B. 2004;60:174-8.

31. Trzesowska A, Kruszynski R, Bartczak TJ. New lanthanidenitrogen bond-valence parameters. Acta Crystallogr B. 2005;61: 429-34.

32. Brown ID. Chemical and steric constraints in inorganic solids. Acta Crystallogr B. 1992;48:553-72.

33. Brese NE, O'Keeffe M. Bond-valence parameters for solids. Acta Crystallogr B. 1997;47:192-7.

34. Shimoni L, Glusker JP, Bock CW. Energies and geometries of isographic hydrogen-bonded networks. 1 . The $R_{2}^{2}(8)$ graph set. J Phys Chem. 1996;100:2957-67.

35. Bernstein J, Shimoni L, Davis RE, Chang NL. Patterns in hydrogen bonding: functionality and graph set analysis in crystals. Angew Chem Int Ed Engl. 1995;34:1555-73.
36. Trzesowska A, Kruszynski R. Channel-containing structure built of $3 \mathrm{D}$ sodium nitrate coordination polymer. J Coord Chem. 2008;61:2167-77.

37. Henry MS, Hoffman MZ. Photophysics and photochemistry of aromatic nitrogen heterocycles. Fluorescence from 2,2'-bipyridine and 1,10-phenanthroline. J Phys Chem. 1979;83:618-25.

38. Eagleson M. Concise encyclopedia chemistry. 2nd ed ed. Berlin: Walter de Gruyter; 1993.

39. Kruszyński R. Synthesis of coordination compounds via dehalogenation of zinc bromoacetate in presence of some amines. Inorg Chim Acta. 2011, Submitted, after revision, Ms No ICA-D10-00647R1.

40. Hensen K, Spangenberg B, Bolte M. Two phenanthroline hydrochlorides. Acta Crystallorg C. 2000;56:208-10.

41. Bernstein MP, Sandford SA, Allamandola LJ, Chang S. Infrared spectrum of matrix-isolated hexamethylenetetramine in $\mathrm{Ar}$ and $\mathrm{H}_{2} \mathrm{O}$ at cryogenic temperatures. J Phys Chem. 1994;98:12206-10.

42. Jensen JO. Vibrational frequencies and structural determinations of hexamethylenetetraamine. Spectrochim Acta Part A. 2002;58: 1347-64.

43. Theo Kloprogge J, Wharton D, Hickey L, Frost RL. Infrared and Raman study of interlayer anions $\mathrm{CO}_{3}{ }^{2-}, \mathrm{NO}_{3}{ }^{-}, \mathrm{SO}_{4}{ }^{2-}$ and $\mathrm{ClO}_{4}{ }^{-}$in Mg/Al-hydrotalcite. Am Miner. 2002;87:623-9.

44. Smith DH, Seshadri KS. Infrared spectra of $\mathrm{Mg}_{2} \mathrm{Ca}\left(\mathrm{SO}_{4}\right)_{3}$, $\mathrm{MgSO}_{4}$, hexagonal $\mathrm{CaSO}_{4}$, and orthorhombic $\mathrm{CaSO}_{4}$. Spectrochim Acta Part A. 1999;55:795-805.

45. Dhandapani M, Thyagu L, Prakash PA, Amirthaganesan G, Kandhaswamy MA, Srinivasan V. Synthesis and characterization of potassium magnesium sulphate hexahydrate crystals. Cryst Res Technol. 2006;41:328-31.

46. Muniz-Miranda M. Surface enhanced raman scattering and normal coordinate analysis of 1,10-phenanthroline adsorbed on silver sols. J Phys Chem A. 2000;104:7803-10.

47. Reiher M, Brehm G, Schneider S. Assignment of vibrational spectra of 1,10-phenanthroline by comparison with frequencies and raman intensities from density functional calculations. J Phys Chem A. 2004;108:734-42. 